\title{
Regulatory Impressionism: What Regulators Can and Cannot Do
}

\author{
RAYMOND L. GIFFORD* \\ The Progress and Freedom Foundation
}

\begin{abstract}
The decision-making process in state utility commissions is best described as "regulatory impressionism." Working in concert with longstanding notions of judicial deference, the existence of regulatory impressionism has far-reaching implications for the move towards a competitive marketplace in the digital age. This article explores how state commissions should operate given a plethora of constraints from both internal and external sources, concluding that the most effective reforms must come from within.
\end{abstract}

\section{Introduction}

There are two large picture frames in the hallway leading to the main hearing room at the Colorado Public Utilities Commission (PUC). The frames contain pictures of those who have served on the Commission. The first portrait is of W.B. Felker, a Colorado Railroad Commissioner from April 7, 1885 - April 9, 1891. The current Chairman's photograph occupies the last-filled slot. ${ }^{1}$ As a reminder of one's impermanence - and an example of prudent capacity planning - the frame has rows of blank spots awaiting the photographs of future commissioners who will be entrusted with regulating the jurisdictional utilities in Colorado.

The historical sweep and personages of the Colorado PUC are displayed in that hallway. The pictured regulators span eras from the late-industrial revolution through the progressive era and, now, to the digital age. A commission that began by regulating railroad lines is now asked to make and implement competition policy for electronic and photonic communications.

This is a dramatic change in subject matter. More to the point, there has been a dramatic change in role. State commissions which once regulated monopolies are now asked to open up markets to competition. Once, commissions like the Colorado PUC had the rather staid job of rate-of-return regulation for monopolies. Now, commissions are charged with implementing delicate and controversial competition policy with the goal of husbanding formerly-closed markets to competition.

\footnotetext{
* Mailing address: President. The Progress \& Freedom Foundation, 1401 H Street, N.W., 10th Floor, Washington DC, 20005. E-mail: rgifford@pff.org The author was the immediate past-Chairman, Colorado Public Utilities Commission, February 1999-January 2003.

${ }^{1}$ The current Chairman is Gregory Sopkin.
} 
It is a fair question, then, whether the commission form of regulation is at all suited to continue into the future as competition and technology transforms the communications marketplace. If some sort of commission regulation at the state level is going to persist, then the question that must be answered is how state commissions should regulate into the future. ${ }^{2}$

How state commissions regulated in the past has been a topic of much inquiry. A number of formal, academic critiques portray regulatory commissions as incentive-laden institutions, displaying private agendas involving self-preservation, regulatory aggrandizement or interest-group capture (Abel, 2002; Peltzman, 1976; Posner, 1974; and Stigler, 1971). Each of these critiques has some explanatory power, as far as it goes. However, like any formal model, they tend to be reductive and unrecognizable in actual regulatory decision-making.

Instead of a formal model, I propose a description about how state regulatory commissions operate and how decisions are made. It has none of the analytical firmness, of say, an interest group capture or the self-aggrandizement model of regulatory behavior. But I think the description more fully captures the texture of regulatory decision-making and activity at the state level. If accurate, then this description will suggest the roles state regulatory commissions ought and ought not play into the future.

It is sometimes said that regulation is an art (as opposed to a science). I therefore borrow a description from the art world, and the famous and beloved movement of the late$19^{\text {th }}$ century, Impressionism. The Impressionist school took an immediate, subjective, and emotive look at the surrounding world, and painted what it saw. Therefore, Impressionist images often appeared to be blurred or in soft-focus. Light and shadows figured prominently in Impressionist art. Monet's famous pond of water lilies - which he painted hundreds of times at varying times of the day and in varying seasons, all to different effect - typifies Impressionist art. There was little deliberation to Impressionist art; to the contrary, Impressionists rebelled against the didactic formalism of earlier artists. They formed impressions of the outside world, and with short, quick strokes, painted those impressions.

Regulatory impressionism shares similar characteristics. ${ }^{3}$ Foremost, it is concerned with the impression any given regulatory action will give to the outside world. It is subjective; non-deliberative; emotive. It works quickly, based on broad impressions and intuitions. It is not schooled in the formal principles of law or economics. Rather, the regulatory impressionist prefers the freedom enjoyed under standards like the "public interest" and "just and reasonable". Regulatory impressionism is not concerned with longterm reactions; nor is it preoccupied with theory or principle. Regulatory impressionism reacts based on the perceived circumstances of the moment, and acts in accordance with those immediate circumstances.

Regulatory impressionism accurately describes the way state commissions regulate. The motives, analysis and actions of state regulators stem from an amalgam of quickly

\footnotetext{
${ }^{2}$ I take it as a given that state commissions will persist in their regulatory roles for the foreseeable future. Institutional inertia, the public choice rewards to be won or lost at the commissions, and the prospect of more elected offices or gubernatorial appointments will keep these institutions relatively vital for years to come. This is not to say I do not share some sympathy with view that the state commissions' role in telecommunications should diminish. However, I believe that the political barriers to such an outcome are formidable. I therefore approach this essay in the spirit of: we have these institutions, what do we now do with them to be a net positive rather than a net negative?

${ }^{3}$ Like painting and other visual arts, the regulatory art can be practiced well or dreadfully.
} 
processed information and decision points. Likewise, the institutional structure of state commissions - how they work and who serves on them - works against deliberated, principled decision-making. ${ }^{4}$

From here, this essay proceeds in four parts. First, I describe the regulatory impressionism that underlies state regulatory action. Second, I deduce from that the core competencies and ability of state commissions. Third, I explain what you would not want a regulatory impressionist doing. Finally, I conclude with a concession and a realization about what state regulators can and cannot do.

In making these suggestions, I draw heavily from my experience as Chairman of the Colorado PUC. While it is always dangerous to universalize from one's own personal experience, I do believe that there are general lessons to be drawn. When I cite to Colorado statutes or regulatory decisions, I do so not because I anticipate that the reader will be rapt about the regulatory decisions made in Colorado during the past four years. Rather, I offer the Colorado experience as the median action at the median-sized state commission with median-quality regulators in charge.

\section{Institutions as they are}

Ronald Coase derides "blackboard economics" as the error of talking about economic principles abstracted from reality. ${ }^{5}$ I would similarly rejoin that we should take regulatory institutions as they are, not as they should be, or divorced from what they actually are. While I cannot testify to the specific institutional circumstances of each and every state commission, there is a commonality at the institutional and commissioner level from which general lessons can be drawn.

State regulatory commissions generally share a common structure stemming from the administrative law revolution from the early part of the twentieth century. ${ }^{6}$ The commission form of regulation has commissioners as decision-makers. In Colorado, the two commissioners and chairman are appointed by the governor to serve terms of four years, and are confirmed by the state senate. ${ }^{7}$ The commissioners are not required by statute to have any particular qualifications or background - the check of the governor's appointment and senate's confirmation power is thought to be enough. Under the commissioners, there is staff tasked with both advising the commission and litigating

\footnotetext{
${ }^{4}$ I hasten to add that I do not regard this as a damning description. Much of the decision-making on state commissions must happen in quick order, over a variety of arcane subject matter, by persons who are not necessarily schooled in the subject matter or applicable legal or economic principles.

${ }^{5}$ Coase (1988, 28-29) described this concept by stating:

Economic policy involves a choice among alternative social institutions, and these are created by the law or dependent on it. The majority of economists do not see the problem in this way. They paint a picture of an ideal economic system, and then, comparing it with what they observe (or think they observe), they prescribe what is necessary to reach this ideal state without much consideration for how this could be done. The analysis is carried out with great ingenuity but it floats in the air. It is, as I have phrased it, "blackboard economics".

${ }^{6}$ I will refer to Colorado statutory law as an example of the state regulatory commission's legal setup. To be sure, there are nuances and differences between the states in each commission's authority and jurisdiction. Nevertheless, the broad template of an administrative agency empowered through administrative procedures to regulate public utilities within the state is consistent across the nation.

${ }^{7}$ Colo. Const. Art. XXV; Colo. Rev. Stat. § 40-2-101.
} 
before it as a party. ${ }^{8}$ The commission acts in both a quasi-legislative capacity in setting rates and passing on tariffs, and a quasi-judicial capacity in hearing complaints and adjudicating rule violations against specific parties. ${ }^{9}$ Either administrative law judges or the commission itself can hear cases and make decisions. ${ }^{10}$ Administrative law judge decisions are appealed to the commission through filing exceptions. ${ }^{11}$ The commission issues its decisions through written orders and public deliberations. ${ }^{12} \mathrm{~A}$ final commission decision can be appealed to the courts.

The commission is granted jurisdiction over "public utilities" operating within the state. In Colorado, this includes jurisdiction over: telecommunications, natural gas, electricity, transportation, water, and railroads. ${ }^{13}$ Most state commissions have jurisdiction over a similar list of industry sectors.

State commissions are funded either from general tax revenues, or through a special tax assessment on jurisdictional utilities, ${ }^{14}$ or a combination of both ${ }^{15}$ State commission staffs vary in size from under 50 in smaller states like North Dakota, South Dakota and Wyoming, to near and over 1000 persons in states like California and New York. There is a rough, but only rough, correlation between state population and the size of the state commission staff. ${ }^{16}$

The commonality of structure matches a commonality of role. It used to be that state commissions regulated monopolies, period. ${ }^{17}$ This involved the certification of utilities to exclusive franchise territories and the regulation of rates, service quality, and terms and conditions of service. The mechanisms for carrying this out evolved along with administrative law - for example, certification hearings, rate cases, tariff filings and orders to show cause. Under monopoly regulation, the state commissions had a discrete set of policy goals: prevent monopoly pricing and output practices; avoid "undue" rate discrimination between rate classes; assure adequate earnings so the regulated utility can serve; promote universal access to the utility system; and ensure public safety (Phillips, 1993, 172-73).

The classic cases of Federal Power Commission v. Hope Natural Gas ${ }^{18}$ (Hope) and Bluefield Water Works \& Improvement Co. v. Public Service Commission of West Virginia $^{19}$ still define the extraordinary discretion granted to commissions. In essence,

\footnotetext{
${ }^{8}$ See Colo. Rev. Stat. § 40-2-101 (ethical rules limit staff to a trial or advisory role in a given case).

${ }^{9}$ Colorado Office of Consumer Counsel v. Mountain States Tel. \& Tel. Co., 816 P.2d 278, 284 (Colo. 1991).

${ }^{10}$ See Colo. Rev. Stat. § 40-6-101.

${ }^{11}$ See Colo. Rev. Stat. § 40-6-109(2).

${ }^{12}$ See Colo. Rev. Stat. § 40-2-106 (written findings); Colo. Rev. Stat. § 24-6-101 et seq. (public deliberations).

${ }^{13}$ See Colo. Rev. Stat. Title 40.

${ }^{14}$ See Colo. Rev. Stat. § 40-6-114; 47 U.S.C. § 252(e)(6).

${ }^{15}$ National Regulatory Research Institute (2003).

${ }^{16}$ The New York and California commissions, in terms of their size and resources, have no peers elsewhere in the nation. It is certainly debatable whether the size of these commissions is a benefit for those states, but they are qualitatively different institutions. A proper taxonomy of the state commissions based on staff size would be tiered: the first-tier would be California and New York, as the resource-rich commissions; the second-tier would be occupied by the Florida, New Jersey, Illinois and Texas Commissions, respectively; and so on

${ }^{17}$ For instance, Colorado still maintains a regulated monopoly for electricity and natural gas and a regulated oligopoly for transportation.

${ }^{18} 320$ U.S. 591 (1944).

${ }^{19} 262$ U.S. $679(1923)$.
} 
these cases hold that the "just and reasonable" standard of rate-setting is co-extensive with the Takings Clause of the United States Constitution. Under the Supreme Court's Hope standard, for instance:

It is not theory but the impact of the rate order that counts. If the total effect of the rate order cannot be said to be unjust and unreasonable, judicial inquiry under the Act is at an end. The fact that the method employed to reach that result may contain infirmities is not then important (Hope, Majority, 602).

The Hope majority further emphasized that the ratemaking process "involves a balancing of the investor and the consumer interests." ${ }^{20}$ As such, the return to equity owners "should be sufficient to assure confidence in the financial integrity of the enterprise, so as to maintain its credit and to attract capital." ${ }^{, 21}$ Even in his dissent from the case upholding a forward-looking rate methodology, Justice Frankfurter noted that "the public interest is a texture of multiple strands." ${ }^{.2}$ However, unlike the majority in Hope, Justice Frankfurter (in support of Justice Jackson) demanded that "the Commission should set forth with explicitness the criteria by which it is guided in determining that rates are "just and reasonable." ${ }^{23}$

The Hope tradition suffuses regulatory decision-making to this day. For quite proper reasons, in Hope and later cases, the courts have said they are not going to get involved in second-guessing fact-intensive, abstruse ratemaking decisions made by state public utility commissions. The courts have taken this approach, in part, for institutional competence reasons. The state, or federal, expert agency is entitled to a presumption that it knows what it is doing, and a court can do no better second-guessing that determination. Accordingly, state commissions are left with extraordinary discretion and latitude in their regulatory decision-making. So long as a decision is not tantamount to a taking under the Fourteenth and Fifth Amendments, ${ }^{24}$ then that decision will be upheld by the courts.

Regulatory proceedings are characterized by an enormous volume of information. The most recent wholesale pricing case in Colorado, a major case to be sure, involved over 2000 pages of testimony, dueling computer models and two weeks of hearings in addition to the written testimony. All of this information was purportedly processed by me (as the hearing commissioner) and five advisors. While this case was going on, the commission carried on a regular agenda, involving the other regulated utility sectors, as well as ongoing proceedings in other telecommunications cases. Information costs, information asymmetry and - given a broader agenda - opportunity costs swamp the ability of a regulator to give careful attention to each and every matter. Nonetheless, there remains enormous legal discretion to work within.

These, then, are the fundamental realities of the state commissions: limited resources, time, and experience; enormous legal discretion and breadth of tasks; and haphazard competence.

\footnotetext{
20320 U.S. at 603.

21320 U.S. at 603

22320 U.S. at 627.

23320 U.S. at $627-628$.

${ }^{24}$ See, for example, Blue Field Water Works, 262 U.S. at 695.
} 


\section{What regulators cannot do}

Regulators' decisions are constrained by the institutional structure, resources and ability of the state commissions. These constraints are formidable, but largely unrecognized in the current inertia. State commissions have been put at the vanguard of implementing competition policy, through no fault of their own. ${ }^{25}$ The Telecommunications Act of 1996 ('96 Act) gives state commissions authority over interconnection, wholesale pricing decisions and Regional Bell Operating Company entry into long distance. ${ }^{26}$ This creates the strange situation where the telecommunications agenda for state commissions has largely been subsumed into implementing federal law. ${ }^{27}$ More troubling, the FCC's implementation of the ' 96 Act has conferred regulatory duties on the states that cannot be performed well, perhaps not by any entity, but certainly not by the states.

Still, state commissions remain nearly unconstrained legally. The applicable Hope legal standards for regulation persist and hence are reliably roomy and broad. "Public interest", "public convenience and necessity", ${ }^{29}$ and "just and reasonable" 30 remain the operative standards under which commissions operate. Indeed, Congress perpetuated the same broad language within the '96 Act, as well. ${ }^{31}$ This creates difficulties because the questions of competition policy are delicate and subtle. The error costs of getting it wrong are high. Yet, the traditional wide berth accorded state commissions works against there being any backstop or standard against which decisions can be evaluated.

The focus of regulatory theory continues to ask state commissions to do things that they cannot do in pursuit of abstract, "blackboard" regulatory theories. To be sure, any regulatory action needs a theory behind it, or at least one would hope. However, there are theoretical models suited to implementation by state commissions, and there are theories that will leave them utterly adrift. Let me explain some of the things regulators are asked to do, and that they cannot do.

In the first instance, utility regulators were asked to constrain monopoly pricing. They did so, ${ }^{32}$ but at the cost of gold-plating and desultory innovation. In addition, the regulation was subject to high information costs and asymmetries. When inflation grew out of hand in the 1970s, the pancaking of rate cases made the regulatory task nearly impossible. Accordingly, at the first and most basic purpose, regulation was found wanting. Indeed, it is easy to see why this failure would occur. The tenets of regulatory impressionism - quick look, limited resources, and limited competence - would naturally lead to exploitation by regulated entities. For instance, given the broad-brush look during a rate case, the regulator will more easily fixate on the authorized rate-of-return on rate base, as opposed to the components of that rate base. Consequently, the rate base can end up inflated, while the

\footnotetext{
${ }^{25}$ See 47 U.S.C. $\$ \S 251,252,271$.

${ }^{26} 47$ U.S.C. $\S \S 251,252,271$.

${ }^{27}$ An interesting side question is whether the various state commissions have authority from their state statutes to participate in implementing a federal statutory scheme. The Colorado PUC (June, 2000: 7) teased authority to participate in the Qwest $\S 271$ filing out of a statute authorizing "consultation" with federal agencies. It is not clear to me if other states have ever searched for such authority.

${ }^{28}$ See, for example, Colo. Rev. Stat. $\S \S 40-1-103,40-15-201$.

${ }^{29}$ See, for example, Colo. Rev. Stat. $\S$ 40-5-102, 40-5-103, 40-5-105, 40-15-202, 40-15-503.

${ }^{30}$ See, for example, Colo. Rev. Stat. $\S \S 40-3-101,40-15-201,40-15-207,40-15-502$.

${ }^{31}$ See 47 U.S.C. $\S \S 160,252(d)(1), 271$; see also Colo. Rev. Stat. § 40-15-503(2)(c)(I)(opening market to competition, but only if it keeps rates "just and reasonable").

${ }^{32}$ For a critique, see Stigler and Friedland (1962).
} 
regulator earns his stripes by clamping down on the rate-of-return. Likewise, because the legal standards are so broad, the regulator can reason-backward from a desired outcome say a rate increase or decrease of $x$ percent - and justify it.

Though ultimately found wanting - and also overtaken by technological progress that eroded the natural monopoly character of the utility industry - asking regulators to constrain monopoly pricing was a low-risk proposition to society. A rate-of-return regulated monopoly could be well-regulated or poorly-regulated, but the difference between the two was slight from a rate perspective. This is because, despite incentives for gaming and information asymmetries, the rate-of-return regulatory method by its nature had stability and resisted dramatic changes in rate structure.

To be sure, this rate-of-return method offered a costly sort of stability in terms of innovation and cost containment. Nevertheless, the regulators had a base line rate base figure to work with and a fairly narrow field of choices for an authorized return on equity. Therefore, absent exogenous factors like the inflation of the 1970s, state regulators had a straightforward job: add up the value of the rate base for the regulated utility and pick an authorized return on equity. An exacting regulator might be able to limit some of the more bloated costs that regulated utilities might try to get into rate base; and a less-exacting regulator might miss some of those same costs. Either way, the margin for error under rateof-return, and the ultimate affect on rates, would be a fraction of overall utility cost recovery. Thus, the first 'blackboard regulatory' act regulators were asked to do could not be accomplished terribly well, but in the grand scheme of things was ultimately not very important to ratepayers in a rate-of-return model.

A related trope of the regulatory task is "mimicking the outcomes of a competitive market (Phillips, 1993, 882)." This issue is repeated endlessly as the starting principle for designing rates. Mimicking the competitive market also has a soothing effect because it involves the regulatory process in the processes of the broader economy, at least rhetorically.

The difficulty with this is where, exactly, does the regulator begin to figure out how to do this? How do you mimic a market when one does not exist in the first place? Rate design purports to aim toward this goal, but in practical application it is almost meaningless. What rates would a competitive market yield? A perfectly competitive market would give prices equal to marginal costs. Yet, if the regulator does think in terms of an industry with a ratio of high fixed to low marginal costs, the regulated entity goes bankrupt rather quickly. The "competitive market" pricing option hence means that the fixed costs need to be recovered by apportioning cost recovery across the rate classes. Second-best efficiency calls for a Ramsey solution, but this ends up looking both indistinguishable from a monopolist's pricing strategy, ${ }^{33}$ and being anathema to social policy considerations because the fixed costs end up on the most demand inelastic customers.

In the end, the rate design mimicking the competitive markets gave way to political necessity. Just the opposite occurred. The regulator - with few legal limits on his discretion - has a much easier time designing a rate structure to serve social and political ends than competitive market pricing concerns. ${ }^{34}$ Indeed, this is just what has happened, particularly in telecommunications. Residential retail rates are kept low and business rates

\footnotetext{
${ }^{33}$ See, for example, Baumol and Sidak (1993).

${ }^{34}$ See, for example, Posner (1971) for a thorough discussion on internal subsidization tendencies.
} 
high, while urban access rates are kept high and rural rates low. Thus, the rates that are supposed to end up mimicking a competitive outcome end up doing just the opposite.

The social costs of these regulatory rate design issues, while non-trivial, ${ }^{35}$ generally go unnoticed. Having persisted for nearly a century, they are either politically tolerable or even politically beneficial. The fact that regulators cannot get these issues right is perhaps a scandal, but only a minor one.

The rate-of-return model obscured great inefficiencies in regulated industries and gave regulated entities the familiar incentive problems to inflate rate base and exploit information asymmetries. However, the ability to redistribute benefits through rate-setting gave state regulators a straightforward job. ${ }^{36}$ Moreover, within the broad discretion of the Hope standard, there was limited supervision as rate structures over time became distorted and regulators gradually lost faith in their ability to know the regulated entities' costs.

The opening of the local exchange market to competition puts all of these past inadequacies in stark relief, however. Errors that once were acceptable or concealed become unsustainable. Errors that are made going-forward have dramatic impacts on the industry and the competitive process as a whole. This is where the Federal Communications Commission (FCC) has gone terribly wrong in asking regulators to do what they reasonably cannot be expected to do.

The FCC has directed the state commissions to price unbundled network elements using Total Element Long-Run Incremental Cost (TELRIC). TELRIC pricing is the epitome of what state commissions cannot do. Adopted by the FCC as part of its First Report and Order, which established the pricing methodology for unbundled network elements, TELRIC is a forward-looking pricing methodology that sets rates premised on the costs of an efficient, up-to-date incumbent, using commercially available technology ${ }^{37}$ Many commentators have assailed TELRIC for its competition policy deficiencies - it subsidizes competitors, encourages over-entry, and kills investment incentives (Kahn, 1998; Kahn, 2001; Sidak and Spulber, 1997; Sidak and Spulber, 1998). While these criticisms are no doubt valid, allow me to add one more to the list: you cannot adjudicate a TELRIC rate in practice and come out with anything resembling a principled answer.

Like the fabled search for rates that mimic market outcomes, there is no analytical or empirical place to begin in pricing a theoretically most-efficient network. To the contrary, the various parties submit computer models that yield widely divergent rates,$^{38}$ based on widely divergent assumptions about the theoretically most-efficient forward-looking network. The familiar regulatory gaming problems from rate-of-return regulation return,

\footnotetext{
${ }^{35}$ Crandall and Waverman (2001) provide a thought-provoking overview of the costs to society of universal service subsidies.

${ }^{36}$ See, Posner (1971).

${ }^{37}$ The Colorado PUC (December, 2001: 10) has described the TELRIC methodology as the following:

TELRIC is a "forward-looking" methodology. Prices are set based upon what it would cost to provide the products and services starting in the present and going forward. The prices are not to be based on the historical costs or investment costs. TELRIC assumes that the company is efficient and is utilizing the most up-to-date, commercially available technology, and network design. In a departure from TELRIC theory, the FCC has determined that the current location of the wire centers should be taken into account. This approach has been referred to as the "scorched node" approach, the network is "scorched" but the "nodes" are left in existence.

${ }^{38}$ Tardiff $(2002,139)$ provides a typical example: "in the most recent Virginia arbitration, Verizon - the ILEC - proposed a loop price of about \$22, while AT\&T and WorldCom advocated a loop cost of about \$6.50.”
} 
only worse. Because the methodology is theoretical and forward-looking, there is more latitude respectively to inflate or minimize costs depending on a party's interests. An incumbent local exchange carrier, seeking maximum cost recovery, will project forwardlooking efficient costs similar to its current, known costs because it wants to recover what it believes are its actual costs, even if they are in the future. Alternatively, a competitive local exchange carrier without its own facilities, will seek to minimize the costs on a future efficient network so that its cost of business is lower.

In the Colorado wholesale pricing proceeding, the Commission described the process of TELRIC ratemaking as being "problematic." The Commission continued:

TELRIC relies on predictions as to the future and analysis based on networks and companies that do not exist. In simple terms, the Commission is called upon to determine what the prices would be if a theoretical, efficient company were to build a telecommunications network starting today, using the most recent technology and bound only by the location of the existing wire centers.

This is no easy feat. For example, as discussed below, a question arises as to whether the rest of the physical world should be considered to exist when considering the fictional build out of a telecommunications network. In addition, the nature of network markets varies dramatically with size and economies of scale. However, a company building a network from scratch would not immediately have the benefits of a sizable network and its economies of scale. Furthermore, the telecommunications technology is changing with sufficient speed and regularity to call into question when the forward look from the Act should begin: the day the pricing docket is opened, today, or the day the Commission's order is released. These notional problems with TELRIC infect the whole of this docket.

The greatest challenge for the Commission, however, is finding an analytic foothold from which to evaluate the respective merits of parties' pricing proposals. Because the pricing methodology is forward-looking and based on hypothetical, efficient, future-built networks, a whole range of plausible assumptions can produce disparate results. Despite the analytic uncertainty of TELRIC pricing, the Commission must nonetheless give its best-informed judgment about the TELRIC rates in Colorado using plausible and reasonable assumptions about the forward-looking costs of the network.

No one single TELRIC price exists for each service or good. Rather a range of reasonable TELRIC prices exists. As long as the prices set by the Commission fall within the TELRIC range of reasonableness, that price will satisfy the FCC's pricing guidelines.

The implications of the preceding discussion are important. First, all pricing efforts, especially those conducted by regulatory agencies, are rough approximations. At best, the TELRIC methodology results in a "range of reasonableness." That the foundation of the FCC's pricing methodology is built on quicksand gives cause for concern. Further pause comes from the information asymmetries inherent in regulatory price setting. In other words, we admit upfront the modesty of our rate setting ability:

Does the Commission believe that it has used appropriate TELRIC methodology? Yes.

Does the Commission believe that it has chosen reasonable inputs to judge forward-looking costs incurred by an efficient firm based on the evidence in this record? Emphatically yes.

The rates set here are based on our best notion of the proper inputs into cost models that purport to yield TELRIC rates. The prices inevitably are the product of art, surmise and informed predication about forward-looking costs (Colorado PUC December, 2001, 12-13).

The TELRIC standard, thus practiced, becomes not a careful, principled analysis of forward-looking rates (that cannot be done because the assumptions are the whole game), but rather a vehicle for creating a margin between wholesale and retail rates. The theory is that, if regulators create enough margin between wholesale and retail, then "competitive" entry will occur in the local exchange market. 
While this quest to create margin may not be "real competition", the behavior comports with the regulators' incentives and abilities. A short time horizon, political pressure to show gains in competitive entry, and a plastic rate methodology - all this gives the regulator ample room to furnish the aesthetics of competition. Thus, the TELRIC ratemaking becomes the vehicle to accomplish vague industrial policy and politically attractive goals.

The FCC, therefore, has given the regulators a methodology in line with their Hope ratemaking discretion, and added to it the political pressure of showing progress in competitive local exchange entry. To be sure, the TELRIC methodology appears to be much more prescriptive than Hope's "just and reasonable" and "public interest" standard. But that is in appearance only. The same amount of discretion exists within TELRIC ratesetting as "just and reasonable" rates because the breadth of allowable and reasonable assumptions about a forward-looking efficient network is enormous. ${ }^{39}$

In the end, these abstract regulatory goals become empty tropes and rhetorical windowdressing for regulators. To be sure, they try to do their best, but ultimately they must make best guesses according to a broad impression of the underlying, operative facts. Also, the discretion allows untoward motivations to creep into regulatory decision-making. Regulators are now under tremendous pressure to show competitive "results" from the '96 Act. ${ }^{40}$ One way to do that is to create sufficient margin between the (still-regulated) retail rates and the wholesale TELRIC rates to induce entry into the local exchange market. Indeed, this is what has been happening, as wholesale TELRIC rates have followed a downward ratchet for some years now. ${ }^{41}$ Since there has been no particular notional change in the expected costs of a future, most-efficient network, the most plausible explanation is that regulators are seeking to induce more costless entry into the local exchange market under the guise of performing a cost analysis. This should be a highly dubious and controversial proposition, but there is no brake on regulators to keep them from reaching for the short-term goal of apportioning market share between competitors.

Given the institutional characteristics of the state commissions, it should be no surprise this has happened. The commissions have broad legal discretion; they have immediate political imperatives to show "competition" in the local exchange market; they have no particular incentive to endure the more-painstaking and uncertain transition to facilitiesbased competition; they have a regulatory tradition that finds ratemaking a congenial undertaking.

\footnotetext{
${ }^{39}$ There is another unremarked, but influential affect on TELRIC ratemaking - eyeballing the rates from other states to fall within a zone of reasonableness. Under this ratesetting method, the states that set TELRIC rates first establish a national baseline for other states to follow. However, because that first decision is not necessarily any more accurate and cannot be based on any empirical rigor, subsequent rates "eyeballed" from that first state are saddled with the implicit assumptions behind that first rate-setting.

${ }^{40}$ Benchmark rates set in comparable states, or the "pressure" of being the state to set the benchmark rate within a service territory in Section 271 proceedings, is a primary example of the results-oriented regime imposed from above. But it is only one of many.

${ }^{41}$ For instance, Gregg's $(2003,1)$ most recent survey of national UNE prices indicates that, between January 2002 and July 2003, average loop rates have fallen 10.3\% while UNE-P rates have fallen 17.3\%, from $\$ 18.95$ per month to $\$ 15.67$ per month. Switching costs have undergone the greatest decline on a UNE-P element basis, dropping $47.9 \%$ over the same time period. The downward ratchet on wholesale rates is curious from a methodological standpoint because there have been no quantum improvements in TELRIC modeling. Rather, the phenomenon is almost surely a product of the quest for increased margin between the wholesale and retail rates where the only rate that is being adjusted is the wholesale one.
} 
The litany of institutional limitations is nothing new. Judge Friendly criticized the federal administrative agencies back in 1962 for:

[t] he failure to develop standards sufficiently definite to permit decisions to be fairly predictable and the reasons for them to be understood (Friendly, 1962, 5-6).

In the transition to a competitive marketplace, this plasticity of standards can be fatal to developing a sustainable competitive communications market. The FCC's directions to the states on implementation of the '96 Act reprised the same invitation that the old Hope "just and reasonable" standard gave during the rate-of-return era. However, the purpose of regulation changed. From formerly constraining monopoly pricing, or at least redistributing benefits among and between ratepayers, state regulators' decisions now affect competition policy.

\section{What regulators can do}

After that panoply of things regulators cannot do, what possibly can there be for them left to do? A glib answer is: not very much. But a more prosaic answer would have a clear, defined role for state commissions. By necessity, this would start by having clear, defined law for state commissions. Unfortunately, the legal discretion of state commissions will not be changed by the legislatures. Accordingly, it is up to the commission itself to constrain itself.

The Hope tradition is fine when the purpose is to regulate a monopoly. But it contains tremendous downside risk when the task is to transition to a competitive marketplace. Accordingly, the applicable legal standards will need to become better defined and more reliable over time.

This can be done in two ways. First, state commissions can actually define concepts like "public interest" and "just and reasonable" to provide more substance and predictability to the standards. In Colorado, the Commission defined the "public interest" standard in merger review cases to be co-extensive with the antitrust "consumer welfare" standard (Colorado PUC, 1999). While the standard remained broad, "consumer welfare" began to anchor the "public interest" inquiry in a body of principled, cognizable antitrust law, as opposed to "can you guess what I am thinking" regulatory law. Second, the state commissions can change their focus from ex ante, prescriptive rulemaking to ex post, dispute-specific complaint resolution. The former role involves rulemaking and prescribing, in advance, the terms, conditions and obligations relating to competition policy. A TELRIC ratemaking is exactly such an undertaking. By shifting their focus to after-the-fact dispute resolution based on specific facts with specific parties, state regulators can avoid making large, global errors; and instead be tethered to specific facts. This will confine the regulatory impressionist to a smaller space, where the regulatory art can be better restrained and focused.

Second, state commissions must return to recognizing their core competencies. Price cap regulation was a great advent of the 1990s. Price caps gave the regulated entities appropriate incentives to innovate, cut costs and realize productivity gains (Laffont and Tirole, 2000, 4-5). However, price cap plans also rested on recognition of the institutional limitations of the regulatory commissions, and of the past-failures of rate-of-return regulation. Because the information costs became lower and the information asymmetries of less concern, price cap plans allowed state commissions to focus on ex post, small-fact 
driven enforcement and complaint matters. ${ }^{42}$ Unfortunately, the glamour of the '96 Act and its return to a regulation-intensive pricing model has obscured the value of 'light touch' regulatory plans that emerged in the $1990 \mathrm{~s} .{ }^{43}$

While light touch regulation like price caps must ultimately be evaluated on its effects on consumers, the strengths of these plans vis-à-vis state commissions' abilities cannot be underestimated. In an environment where regulatory impressionism is the dominant mode of review, price caps and other performance-based models relieve commissions of the high-error, high-intensity, high-theory work of cost-based regulation.

Additionally, state commissions can broaden deregulation so that their ex ante prescription of pricing or earnings or terms and conditions melts away completely. Price cap plans in the 1990s were one such innovation. So long as the initial price cap plan was roughly sound - and so long as the regulators honored the plan - then the persistent problems of regulatory caprice and information-gathering were minimized. The freeing up of Commission time from cost-based regulation also should allow commissions to focus on smaller, fact-based inquiries based on ex post enforcement. ${ }^{44}$ This might take the form of a carrier-to-carrier complaint or a consumer-to-carrier complaint, but such proceedings better fit the regulatory impressionist's abilities. For one, the stakes are not too high and the theorizing not too grand in ex post complaint proceedings. Also, the ex post complaint proceeding is anchored to specific, small facts instead of large, theoretical surmise. This is something that regulators can do with comparative advantage in expertise, speed and principle.

\section{Conclusion}

There is a sentimentalism that state commissions can be "laboratories of democracy," 45 innovating and designing novel regulatory plans for transitions to competition. Truth be told, state regulators do not have the time, resources, or abilities to innovate or found new schools of competition policy. The regulatory impressionist can make quick judgments, based on broadly comprehended facts, aimed toward a short time-horizon. These are not insubstantial skills, but they bespeak roles that involve case-by-case decision-making on discrete facts, between discrete parties. An impressionist can paint a specific landscape, in a specific place, but if you ask him to paint the entire world, it just becomes a muddled blur to both the painter and the viewer.

In the end, regulators cannot do much more than they can do. Burdened with multiple subject-matter jurisdictions, limited background and training in the subject matter of network economics, limited resources, and limited means to get the "right" regulatory

\footnotetext{
42 The Colorado price cap plan was adopted in February 1999. See Colorado PUC, In the Matter of U S West, Inc. for Specific Forms of Price Regulation, Decision No. C99-222. Docket No. 97A-540T (Feb. 2, 1999).

${ }^{43}$ In retrospect, the '96 Act's explicit call for cost-based pricing standards, with additional pressure upon the FCC to induce rapid competitive entry, merged to cause the Commission to drop its preference for price caps.

${ }^{44}$ To be sure, there still should be an oversight presence to police an incumbent's obvious incentives to block competitive entry. But, this can be an after-the-fact, fact-driven inquiry triggered by a complaint process rather than an ex ante "predict the future" plan.

${ }^{45}$ New State Ice Co. v. Liebmann, 285 U.S. 262, 311, 52 S.Ct. 371, 386 (1932) (Brandeis, J., dissenting) (arguing for state of Oklahoma's right to regulate sale of ice as a public utility).
} 
answers, it is a wonder that state regulatory institutions can manage the job at all. There can be all sorts of fanciful calls for better education, more resources, or better, smarter regulators, but these calls have little chance of reaching legislatures or governors. Accordingly, the regulatory model must be changed from the inside by devising regulatory programs that minimize or avoid some of the institutional inadequacies of state commissions, and at the same time provide clear, stable rules of decision-making for a competitive industry going-forward.

I hold out no great hope that the regulatory impressionist will learn to focus on the smaller, ex post corner of the world where his expertise and relative ability to respond quickly would be of value. The institutional incentives just cut too far against this modest view of what regulators can and should do. Nonetheless, if we take state regulation as it is, and try to say what it should be, that is a modest offering about where we might end up.

\section{$6 \quad$ References}

Abel, J. (2002) "Entry into Regulated Monopoly Markets: The Development of a Competitive Fringe in the Local Telephone Industry," The Journal of Law and Economics, 45: 289-316.

Baumol, W. and J. Sidak (1993) Towards Competition in Local Telephony, American Enterprise Institute for Public Policy Research.

Coase, R.H. (1988) The Firm, the Market, and the Law, The University of Chicago Press.

Colorado Public Utilities Commission (1999) In the Matter of the Application of Public Service Company of Colorado for Commission Authorization for New Century Energies, Inc. to Merge With Northern States Power Company, Order (1) Granting, In Part, and Denying, in Part, Public Service's Motion to Define Scope of Proceeding, (2) Granting Motion Requesting Approval of Procedural Schedule, and (3) Establishing Procedures. Decision No. C99-1052, Docket No. 99A-377EG.

Colorado Public Utilities Commission (2001) In the Matter of U S West Communications, Inc. 's Statement of Generally Available Terms and Conditions, Decision No.C01-1302, Docket No. 99A-577T.

Colorado Public Utilities Commission (2002) In the Matter of the Investigation of $U S$ West Communications, Inc. 's Compliance with \$271(c) of the Telecommunications Act of 1996, Decision No. R00-612-I, Docket No. 97I-198T.

Crandall, R. and L. Waverman (2000) Who Pays for Universal Service? Brookings Institution Press.

Federal Communications Commission (1996) Implementation of the Local Competition Provisions in the Telecommunications Act of 1996, CC Docket 96-98, First Report and Order, FCC 96-325. 
Friendly, H. (1962) The Federal Administrative Agencies: The Need for Better Definition of Standards, Harvard University Press.

Gregg, B. (2003) "A Survey of Unbundled Network Element Prices in the United States,"

National Regulatory Research Institute, http:/www.nrri.ohiostate.edu/documents/intro0703.pdf

Kahn, A. (1998) Letting Go: Deregulating the Process of Deregulation, The Institute of Public Utilities and Network Industries.

Kahn, A. (2001) Whom the Gods Would Destroy, or How Not to Deregulate, AEIBrookings Joint Center for Regulatory Studies.

Laffont, J. and J. Tirole (2000) Competition in Telecommunications, The MIT Press.

National Regulatory Research Institute (2003) "State Regulatory Commission Budget Reductions and Cost Containment: Results of a Survey," http://www.nrri.ohiostate.edu/phpss113/search.php?focus $=02-16 \&$ select=Publications

Peltzman, S. (1976) "Toward a More General Theory of Regulation," The Journal of Law and Economics, 19: 211-40.

Phillips, C. (1993) The Regulation of Public Utilities: Theory and Practice, 3rd Ed., Public Utilities Reports, Inc.

Posner, R. (1974) "Theories of Economic Regulation," Bell Journal of Economics and Management Science, 5: 335-58.

Posner, R. (1971) “Taxation by Regulation,” Bell Journal of Economics, 2: 22-50.

Sidak, J. and D. Spulber (1997) "The Tragedy of the Telecommons: Government Pricing of Unbundled Network Elements Under the Telecommunications Act of 1996," Columbia Law Review, 97: 1081-1161.

Sidak, J. and D. Spulber (1998) Deregulatory Takings and the Regulatory Contract: The Competitive Transformation of Network Industries in the United States, Cambridge University Press.

Stigler, G. (1971) "The Theory of Economic Regulation," Bell Journal of Economics and Management Science, 2: 3-21.

Stigler, G. and C. Friedland (1962) "What Can Regulators Regulate? The Case of Electricity," The Journal of Law and Economics, 5: 1-16.

Tardiff, T. (2002) "Pricing Unbundled Network Elements and the FCC's TELRIC Rule: Economic and Modeling Issues," Review of Network Economics, 1: 132-46. 